\title{
Low-dose oral immunization with lyophilized tissue of herbicide-resistant lettuce expressing hepatitis B surface antigen for prototype plant-derived vaccine tablet formulation
}

\author{
Tomasz Pniewski • Józef Kapusta $\cdot$ Piotr Bociąg • Jacek Wojciechowicz $\cdot$ \\ Anna Kostrzak • Michał Gdula • Olga Fedorowicz-Strońska • Piotr Wójcik • \\ Halina Otta $\cdot$ Slawomir Samardakiewicz $\cdot$ Bogdan Wolko $\cdot$ Andrzej Plucienniczak
}

Received: 18 August 2010 /Revised: 11 October 2010 /Accepted: 12 October 2010/Published online: 23 November 2010

(C) The Author(s) 2010. This article is published with open access at Springerlink.com

\begin{abstract}
Efficient immunization against hepatitis B virus (HBV) and other pathogens with plant-based oral vaccines requires appropriate plant expressors and the optimization of vaccine compositions and administration protocols. Previous immunization studies were mainly based on a combination of the injection of a small surface antigen of HBV (S-HBsAg) and the feeding with raw tissue containing the antigen, supplemented with an adjuvant, and coming from plants conferring resistance to kanamycin.
\end{abstract}

Tomasz Pniewski and Józef Kapusta contributed equally to this work.

T. Pniewski $(\bowtie) \cdot J$. Kapusta $\cdot$ P. Bociag $\cdot$ A. Kostrzak

M. Gdula $\cdot$ O. Fedorowicz-Strońska $\cdot$ B. Wolko

Institute of Plant Genetics, Polish Academy of Sciences,

Strzeszyńska 34,

60-479 Poznań, Poland

e-mail: tpni@igr.poznan.pl

J. Kapusta • O. Fedorowicz-Strońska • A. Płucienniczak Institute of Biotechnology and Antibiotics,

Starościńska 5,

05-216 Warszawa, Poland

J. Wojciechowicz

DNA Research Centre Ltd.,

Rubież 46,

61-612 Poznań, Poland

P. Wójcik $\cdot$ H. Otta

Institute of Medicinal Plants,

Karola Libelta 27,

61-707 Poznań, Poland

S. Samardakiewicz

Faculty of Biology, Adam Mickiewicz University,

Umultowska 89,

61-614 Poznań, Poland
The objective of this study was to develop a prototype oral vaccine formula suitable for human immunization. Herbicide-resistant lettuce was engineered, stably expressing through progeny generation micrograms of S-HBsAg per $g$ of fresh weight and formed into virus-like particles (VLPs). Lyophilized tissue containing a relatively low, 100-ng VLP-assembled antigen dose, administered only orally to mice with a long, 60-day interval between prime and boost immunizations and without exogenous adjuvant, elicited mucosal and systemic humoral anti-HBs responses at the nominally protective level. Lyophilized tissue was converted into tablets, which preserved S-HBsAg content for at least one year of room temperature storage. The results of the study provide indications on immunization methodology using a durable, efficacious, and convenient plant-derived prototype oral vaccine against hepatitis B.

Keywords Anti-HBV oral vaccine - Lyophilized plant tissue - Oral immunization · Plant-based vaccines . S-HBsAg · Transgenic lettuce

\section{Introduction}

In the last 25 years, essential progress has been made in prophylaxis against hepatitis B (HB) using one of the most effective and cheapest recombined vaccines (Goldstein and Fiore 2001). However, one third of the worldwide human population is still suffering from $\mathrm{HB}$ and the number of hepatitis B virus (HBV) chronic carriers is constantly growing, mainly in developing countries (Kao and Chen 2002). Insufficient medical infrastructure causes delays or even failure of mass-scale HB vaccination programs. Thus, 
reliable and easily implementable prevention methods are desirable. Oral vaccines, including plant-based formulations, are considered as alternatives or supplements for standard injection vaccines, since they have the potential for simplified vaccination procedures against pathogens penetrating through mucosal membranes or blood (Aziz et al. 2007; Mestecky et al. 2008).

Research on the development of an oral plant-based vaccine against the $\mathrm{HBV}$ and other pathogens has been conducted for over 15 years. The small HBV surface antigen (S-HBsAg) was expressed in tobacco, potato, lettuce, and other plants, as well as in tissue and cell suspension cultures. Anti-HBs immune response triggered by the oral administration of plant material containing SHBsAg was shown both in mice (Kapusta et al. 1999; Richter et al. 2000; Kong et al. 2001; Gao et al. 2003; Joung et al. 2004) and in humans (Kapusta et al. 1999, 2001; Mason et al. 2003; Thanavala et al. 2005). However, despite some successes, reproducible and long-lasting oral immunization by feeding proved to be extremely difficult in terms of the control of the immunization regime, raw plant material storage, and its inconvenient administration, which all might potentially lead to tolerance induction (Kirk et al. 2005). Moreover, previously used plants containing SHBsAg exhibited resistance to antibiotics, which limits their application only to laboratory experiments.

We present here an approach to oral vaccines based on the low-dose administration of lyophilized tissue, derived from lettuce expressing S-HBsAg at a high level and resistant to glufosinate-derived herbicides, as the only selection marker. Lettuce was chosen as a vaccine producer since it represents a plant naturally free of harmful substances, adaptable for cultivation in various conditions, and simple for processing into formulas of a potential oral vaccine. Freeze-dried material containing S-HBsAg without exogenous adjuvants, administered to mice under a controlled regime, induced a mucosal and peripheral humoral response above the nominal protective titer. Lyophilized material, both a powdered semi-finished product or converted into tablets, preserved the antigen for at least one year. The presented results can facilitate the development of efficient, durable, and convenient plant-based oral vaccines for prophylaxis against HB and other diseases.

\section{Materials and methods}

Construction of the plant transformation vector

The coding region of S-HBsAg of $681 \mathrm{bp}$ in length was amplified on a template of the plasmid pHB321 containing the complete genome of HBV subtype ayw4 (GenBank accession no. Z35716), using the following primers introducing $\operatorname{Bam} \mathrm{H}$ I and Pst I restriction sites, respectively: 5'-GGATCCATGGATCCATGGAGAACATCACATCAG-3' (forward) and 5'-CTGCAGTAGAGCTCTTAAATGTATACCCAGAGA-3' (reverse). The amplified fragment was cloned into the pMG2A plasmid, a derivative of pUC18 containing the 35 S RNA CaMV promoter (p35S) and nopaline synthase terminator (NOSt). The expression cassette p35S-SHBsAgNOSt was cloned into the EcoR I and Hind III sites of pGPTV-BAR (Becker et al. 1992), replacing the GUS gene. The yielded vector pKHBSBAR (Fig. 1), carrying the bar gene conferring resistance to glufosinate, was introduced into Agrobacterium tumefaciens EHA105 via electroporation.

\section{Lettuce transformation, regeneration, and cultivation}

Agrobacterium tumefaciens was cultured and prepared for explant inoculation as previously described (Pniewski and Kapusta 2005), but Agrobacterium was grown until $\mathrm{OD}_{550} \approx$ 1.0. Seeds of lettuce (Lactuca sativa L.) cv. Syrena were sterilized for $12 \mathrm{~min}$ with $20 \% \mathrm{v} / \mathrm{v}$ chloric bleach supplemented with $0.01 \% \mathrm{v} / \mathrm{v}$ Tween ${ }^{\circledR} 20$, washed 5-6 times with distilled water, and germinated on solidified $0.8 \% \mathrm{w} / \mathrm{v}$ agar (Serva) in the semi-shade at $25^{\circ} \mathrm{C}$ for $2-3$ days. Cotyledons were then excised, inoculated in the Agrobacterium suspension for 10-15 min, dried briefly, and transferred onto the LR1 medium consisting of MS salts and vitamins, $3 \% \mathrm{w} / \mathrm{v}$ sucrose, $0.2 \mathrm{mgL}^{-1}$ of 6-benzylamminopurine, and $0.05 \mathrm{mgL}^{-1}$ of naphthaleneacetic acid and co-cultured for 2 days in darkness at $25^{\circ} \mathrm{C}$. Explants were transferred once a week onto fresh LR1 selection medium, i.e., supplemented with $2.5 \mathrm{mgL}^{-1}$ of glufosinate (Sigma) and $300 \mathrm{mgL}^{-1}$ of Timentin. Calli with adventitious buds were transferred onto the LR2 selection medium consisting of $\mathrm{SH}$ salts, B5 vitamins, $3 \% \mathrm{w} / \mathrm{v}$ sucrose, $0.5 \mathrm{mgL}^{-1}$ of kinetin, and $0.5 \mathrm{mgL}^{-1}$ of zeatin. Developed plantlets were excised and

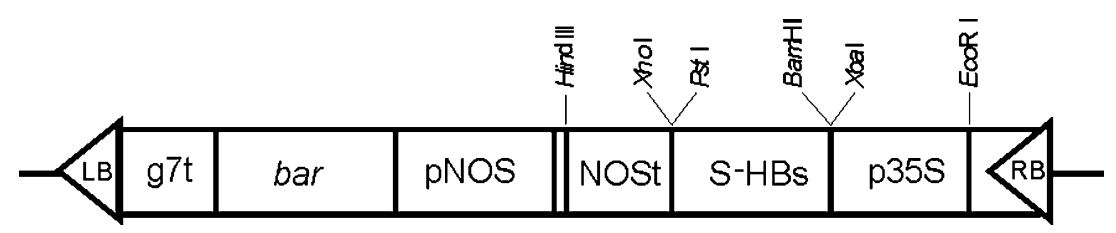

Fig. 1 Organization of T-DNA of the binary plasmid pKHBSBAR. SHBs, coding sequence of small surface antigen of HBV; bar, coding sequence of phosphinothricin acetyltransferase; p35S, CaMV $35 \mathrm{~S}$ promoter; pNOS, nopaline synthase promoter; NOSt, nopaline synthase terminator; $\mathrm{g} 7 \mathrm{t}, \mathrm{g} 7$ terminator; $\mathrm{LB}$ and $\mathrm{RB}$, left and right $\mathrm{T}$ DNA border sequences 
transferred onto a rooting selection medium LR3, consisting of half the amount of SH macroelements, but the full amount of SH microelements, B5 vitamins, and 3\% w/v sucrose. All media were adjusted to $\mathrm{pH} 5.7$ and solidified with $0.8 \%$ agar (Serva). In vitro cultures were conducted under $4,000 \mathrm{~lx}$ of light intensity, $16 / 8$-h photoperiod, and at a $25 / 18^{\circ} \mathrm{C}$ temperature regime. Rooted plants were transferred into soil and grown in a greenhouse under 15-20 klx light intensity, $16 / 8$-h photoperiod, and at a $22 / 16^{\circ} \mathrm{C}$ temperature regime. Harvested seeds were surface-sterilized and germinated as above on a half-strength MS medium with $2.5 \mathrm{mgL}^{-1}$ of glufosinate. Seedlings of progeny plants were transferred into soil and cultivated as described above.

PCR and Southern blot analysis

Genomic DNA was extracted from leaves in a small-scale procedure according to McGarvey and Kaper (1991). Polymerase chain reactions (PCRs) were performed in a PTC-200 MJ Research thermal cycler, in a volume of $25 \mu \mathrm{l}$ containing approximately $100 \mathrm{ng}$ of plant genomic DNA, $10 \mathrm{pM}$ of each of the above-mentioned primers, $0.2 \mathrm{mM}$ of each dNTP, $3.5 \mathrm{mM} \mathrm{MgCl}_{2}$, and 1 unit of Taq DNA polymerase (Invitrogen). The PCR temperature profile was as follows: initial denaturation at $94^{\circ} \mathrm{C}$ for $4 \mathrm{~min}$, then 35 cycles of denaturation at $94^{\circ} \mathrm{C}$ for $1 \mathrm{~min}$, annealing at $68^{\circ} \mathrm{C}$ for $45 \mathrm{~s}$, elongation at $72^{\circ} \mathrm{C}$ for $1 \mathrm{~min}$, and final extension at $72^{\circ} \mathrm{C}$ for $5 \mathrm{~min}$. The molecular weight of PCR products was estimated by agarose gel electrophoresis using the 200 bp DNA Ladder (MBI Fermentas).

DNA for Southern hybridization was extracted according to Doyle and Doyle (1990), cut with the EcoR I, run on $0.75 \%$ agarose gel, and then blotted onto a positively charged membrane (Roche). The probe specific to the S-HBs sequence was prepared by PCR using a DIG DNA Labeling Kit (Roche), hybridized according to the manufacturer's protocol, and signals were detected on an X-ray film using CSPD (Roche) as a chemiluminescent substrate.

\section{TEM}

Lettuce leaf tissue was prepared for transmission electron microscopy (TEM) according to the standard technique with slight modifications (Kocjan et al. 1996). Ultrathin sections of approximately $70 \mathrm{~nm}$ in thickness were obtained using an UltraCut S microtome (Leica Microsystems) and observed under a JEM1200EXII transmission microscope (Jeol).

\section{Western blot of S-HBsAg}

Leaf pieces, approximately $50-60 \mathrm{mg}$ in weight, were ground in $300 \mu \mathrm{l}$ of PBS buffer with $0.5 \% \mathrm{v} / \mathrm{v}$ Tween ${ }^{\circledR} 20$, then Laemmli buffer with DTT was added and samples were incubated at $65^{\circ} \mathrm{C}$ for $15 \mathrm{~min}$. Samples were run under denaturing conditions $(12 \% \mathrm{w} / \mathrm{v}$ polyacrylamide gel with $0.1 \% \mathrm{w} / \mathrm{v}$ SDS) and then blotted onto a nitrocellulose membrane (Roche). The blot was blocked with $3 \% \mathrm{w} / \mathrm{v}$ BSA in TBS buffer, then incubated with 1:4,000 TBSdiluted anti-SHBsAg rabbit serum (University of Gdańsk,

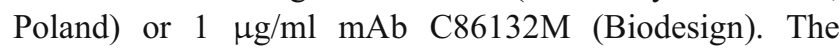
1:10,000 TBS-diluted anti-rabbit or anti-mouse wholemolecule polyclonal HRP-conjugated antibody (Sigma) was used as a secondary antibody. The molecular weight of protein bands, visualized after a reaction with the DAB substrate (Sigma), was estimated using a protein marker (MBI Fermentas).

ELISA assay of S-HBsAg in lettuce leaves, lyophilized plant tissue, and derived tablets

Samples were ground in a mortar on ice in a gradually added extraction buffer consisting of PBS pH 7.4, $10 \mathrm{mM}$ $\mathrm{Na}_{2} \mathrm{SO}_{3}, 2 \% \mathrm{w} / \mathrm{v} \mathrm{PVP} 40000,0.2 \% \mathrm{w} / \mathrm{v}$ BSA, and $1 \% \mathrm{v} / \mathrm{v}$ Tween ${ }^{\circledR} 20$. Crude extracts were centrifuged at $10,000 \mathrm{rpm}$ at $4^{\circ} \mathrm{C}$ for $10 \mathrm{~min}$. The ratio of extraction buffer volume to the sample weight was 25:1 for leaf and 200:1 for lyophilized tissue or tablet.

The quantitative enzyme-linked immunosorbent assay (ELISA) was performed according to typical guidelines with details specific for the S-HBsAg assay set as follows. A Microtiter MaxiSorp (Nunc) microplate was coated overnight at $4^{\circ} \mathrm{C}$ with $0.5 \mu \mathrm{g} / \mathrm{ml} \mathrm{mAb} \mathrm{C86132} \mathrm{(Biodesign)}$ in carbonate buffer $\mathrm{pH} 9.6$ and then saturated for $2 \mathrm{~h}$ at $25^{\circ} \mathrm{C}$ with $5 \% \mathrm{w} / \mathrm{v}$ PBS-fat-free milk. Typically, extracts were added to PBS-filled wells and serially diluted 1:100 1:800 for leaf samples or 1:800-1:6,400 for lyophilized tissue or tablet samples. Afterwards, wells were incubated with 1:4,000 anti-SHBsAg polyclonal rabbit antibody (B65811R, Biodesign), then with 1:20,000 anti-rabbit IgG $\gamma$-specific biotin-conjugated mAb (Sigma), followed by 1:4,000 AP-conjugated ExtrAvidin ${ }^{\circledR}$ (Sigma). The reaction with pNPP substrate (Sigma) was developed at $25^{\circ} \mathrm{C}$ for 1 $\mathrm{h}$ and absorbance was measured at $405 \mathrm{~nm}$ using a Bio-Rad Microplate Reader, Model 680. The S-HBsAg concentration (microgram per gram of fresh or dry weight, $\mu \mathrm{g} / \mathrm{g}$ FW or $\mu \mathrm{g} / \mathrm{g}$ DW, respectively) was calculated as the arithmetic mean with standard deviation (SD) from three (lettuce leaves) or ten (lyophilized tissue and tablets) repeated assays, using Microplate Manager 5.2.1 software (Bio-Rad), according to the standard curve for unadjuvanted S-HBsAg (University of Ulm, Germany) in the negative control extract.

As a reference to the above polyclonal ELISA test for the total content of S-HBsAg, plants were screened using an Auszyme ${ }^{\circledR}$ Monoclonal Diagnostic Kit (Abbott) for the virus-like particle (VLP)-assembled antigen. The samples 
were extracted as above and assayed according to the provided protocol.

Preparation of lyophilized plant material and tablets

Leaves from lettuce lines of S-HBsAg content $\geq 10 \mu \mathrm{g} / \mathrm{g}$ FW were frozen in liquid nitrogen, then partially crumbled and freeze-dried (BETA 1-16, CHRIST $^{\circledR}$ ) in vacuum at $0.2 \mathrm{mbar}$ and $-30^{\circ} \mathrm{C}$, for $36-72 \mathrm{~h}$. Lyophilized tissue was powdered in a coffee-mill chilled on ice and stored at room temperature with silica gel, tightly sealed. For tablet preparation, the material was mixed with different fillers and binding agents. Finally, tablets were prepared from $2: 1: 1 \mathrm{w} / \mathrm{w} / \mathrm{w}$ mixture of tissue powder with lactose (Meggle) and 10\% w/v polyvinylpyrrolidone (BASF) in methylene chloride (Merck). The mixture was granulated into grains of $1 \mathrm{~mm}$ in diameter. Granules were mixed with $2 \% \mathrm{w} / \mathrm{v}$ magnesium stearate and then formed in a stamping press (Korsch) into tablets.

\section{Mouse immunization}

Mouse immunization studies were conducted with approval no. 35/2004 of the Local Bioethical Commission at the Medical University of Warsaw. Separate groups of 6-8-week-old 10 $\mathrm{BALB} / \mathrm{c}$ mice were immunized with powdered lyophilized plant tissue containing S-HBsAg or the purified and alumadsorbed yeast-derived antigen from a commercial vaccine Engerix $B^{\circledR}$ (GlaxoSmithKline) at 30- or 60-day intervals. A single dose of VLP-assembled S-HBsAg was $100 \mathrm{ng}$, suspended in $100 \mu \mathrm{l}$ of PBS, and administered by gavage intubation. Directly before immunization, VLP-S-HBsAg was assayed by the Auszyme ${ }^{\circledR}$ kit to deliver an appropriate amount of the lyophilized plant material (ca. $9 \mathrm{mg} /$ dose). Control mice were given lyophilized non-transgenic tissue or PBS every 60 days.
ELISA assay of anti-HBs antibodies and statistical analysis of immune response

Blood and feces were collected 5 days before (pre-immune) and 10 days after each immunization. Sera were collected from blood centrifuged at $3,000 \mathrm{rpm}$ at $4^{\circ} \mathrm{C}$ for $10 \mathrm{~min}$. Antibodies were extracted from feces by suspending samples in five volumes (w/v) of PBS and incubation on ice for $15 \mathrm{~min}$, twice repeated grinding and incubation on ice for $15 \mathrm{~min}$, and shaking and centrifugation at $14,000 \mathrm{rpm}$ at $4^{\circ} \mathrm{C}$ for $10 \mathrm{~min}$. Anti-HBs antibodies $(\mathrm{mIU} / \mathrm{ml})$ were assayed twice using a Hepanostika ${ }^{\circledR}$ kit with quantitative standards (Organon Teknika, Boxtel) and analyzed statistically (the variance for one-way classification with repeated measurements, the Tukey and Duncan tests, $p<0.05)$ using Statistica $6{ }^{\circledR}$ software (StatSoft).

\section{Results}

S-HBsAg expression in glufosinate-resistant transgenic lettuce plants

The efficiency of lettuce transformation amounted to $13 \%$, i.e., 25 verified (out of 28) PCR-positive for S-HBs sequence, individual glufosinate-resistant transgenic lines were regenerated from 190 explants. The S-HBs sequence was detected by $\mathrm{PCR}$ in $\geq 75 \%$ of the $25-35$ progeny (T1) plants of each analyzed line (Fig. 2a), and in most lines, Southern blot analysis confirmed 1-2 integration sites of T-DNA (Fig. 2b).

The primary (T0) transformants significantly differed regarding the total S-HBsAg expression $(20 \mathrm{ng}$ to $60 \mu \mathrm{g} / \mathrm{g}$ FW), hence, they were distinguished into three expression groups, i.e., of 'low' antigen level $\leq 5 \mu \mathrm{g} / \mathrm{g} \mathrm{FW}$, 'medium' 5-10 $\mu \mathrm{g} / \mathrm{g} \mathrm{FW}$, and 'high' $\geq 10 \mu \mathrm{g} / \mathrm{g} \mathrm{FW}$ (Fig. 3). The SHBsAg content was maintained or increased in plants of the

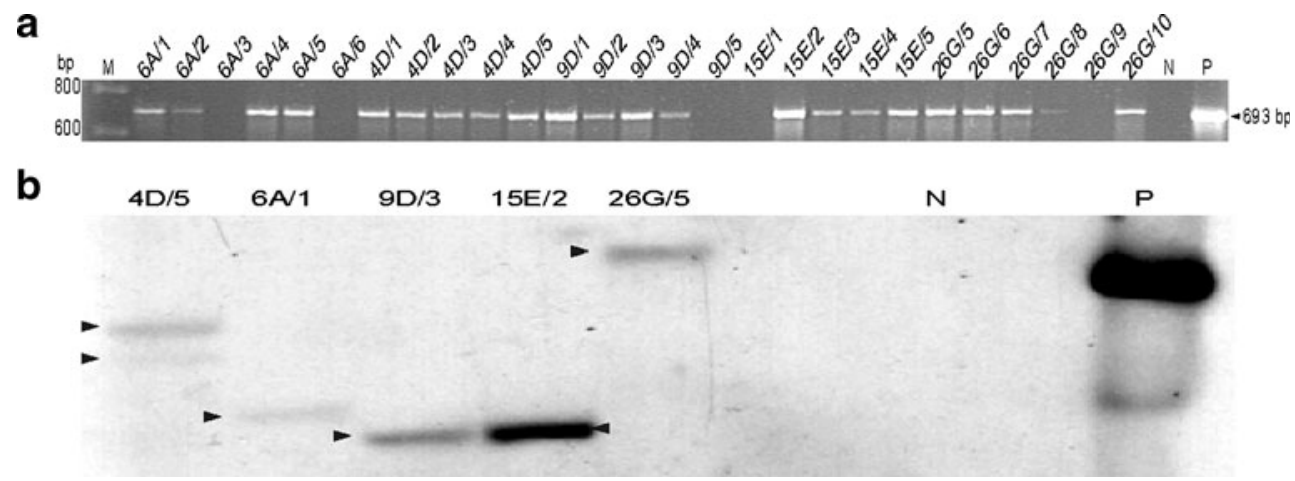

Fig. 2 a, b Inheritance of the S-HBs transgene in lettuce plants of T1 generation. a PCR analysis using primers designed to the S-HBsAg coding sequence to amplify a 693-bp product. Lanes: $M$ DNA size marker (200 bp DNA Ladder, MBI Fermentas); 6A/1-26G/10 analyzed plants; $N$ non-transgenic plant (negative control); $P$
pKHBSBAR plasmid (positive control). b Southern blot analysis of integrated T-DNA in genomic DNA using a probe complementary to the S-HBs sequence. Lanes: $4 D / 5-26 G / 5$ analyzed plants; $N$ nontransgenic plant (negative control); $P$ pKHBSBAR plasmid (positive control) 


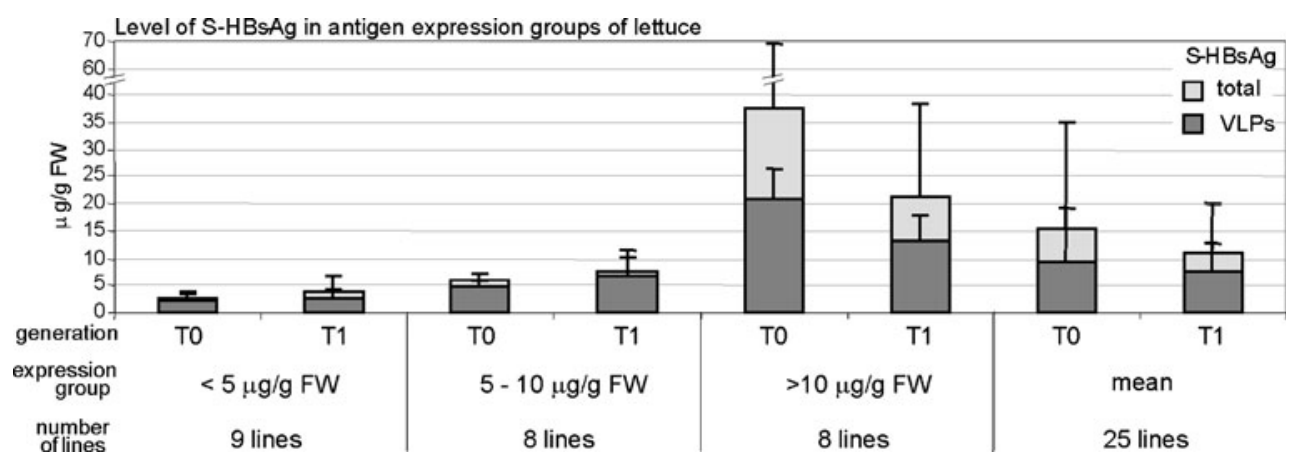

Fig. 3 Expression of total and VLP-assembled S-HBsAg in lettuce plants of T0 and T1 generation. Plants of T0 generation were divided into three expression groups, depending on the total S-HBsAg level calculated in $\mu \mathrm{g} / \mathrm{g}$ of fresh weight $(\mathrm{FW})$ : low $<5 \mu \mathrm{g} / \mathrm{g} \mathrm{FW}$, medium 5$10 \mu \mathrm{g} / \mathrm{g} \mathrm{FW}$, high $>10 \mu \mathrm{g} / \mathrm{g} \mathrm{FW}$. The data show values calculated as

T1 generation for most lines of the 'low' or 'medium' groups. Significant fluctuations and decrease of antigen expression or some phenotype alterations, e.g., retarded growth or a low number of seed sets, were observed only for a few lines, mostly from the 'high' group. Finally, 12 lines of stable S-HBsAg content $\geq 5 \mu \mathrm{g} / \mathrm{g}$ FW were selected for further research, including 'high' lines designed for lyophilization. The content of S-HBsAg formed in tertiary structures, i.e., displaying immunodominant epitope ' $a$ ' when properly folded and assembled into VLPs, was estimated using an monoclonal Auszyme ${ }^{\circledR}$ kit (Abbott), being approximately $60-85 \%$ of the total values calculated by the polyclonal ELISA (Fig. 3). The expression of SHBsAg assembled into dimers, both non-glycosylated (48 kDa, p48) and putative glycosylated (54 kDa, gp54), was also confirmed by Western blot analysis (Fig. 4). VLPs formed by plant-expressed S-HBsAg were directly observed in leaf cells using TEM (Fig. 5a, c), while they were not detected in non-transgenic lettuce (Fig. 5b). Observed plant VLPs were 17-22 $\mathrm{nm}$ in diameter, characteristic of native or yeast-derived purified VLPs (Fig. 5d).

Mouse immunization with lyophilized plant tissue containing S-HBsAg

Several trends in local and systemic humoral immune responses were observed after the oral delivery of $100 \mathrm{ng} /$ dose of VLP-assembled S-HBsAg, both plant-derived in powdered lyophilized tissue (ca. $9 \mathrm{mg} /$ dose, coming from plants of $\geq 10 \mu \mathrm{gS}-\mathrm{HBsAg} / \mathrm{g} \mathrm{FW}$ ) or the purified and alumadsorbed antigen (Fig. 6). Anti-HBs antibodies, both secretory $\operatorname{IgA}(\mathrm{S}-\operatorname{Ig} \mathrm{A})$ in feces (Fig. 6a) and total serum antibodies (Fig. 6b), were induced at similar levels in all individual mice of particular groups, as demonstrated by low SDs. Immune response was clear and statistically significant for each immunization protocol, but more efficient for the longer schedule. The final levels of anti-HBs the arithmetic mean and standard deviation (SD) from three assays for parental or $25-35$ progeny plants, determined by polyclonal ELISA for total antigen or by the monoclonal Auszyme ${ }^{\circledR}$ diagnostic kit (Abbott) for VLP-assembled antigen

antibodies were similar for reactions induced by the plant-derived or purified antigen administered every 30 days, but for the 60-day schedule, plant-derived antigen elicited a higher immune response, especially in the mucosa. The systemic response was lower than that in the intestinal mucosa, approximately 3-4 times lower after priming and almost 2 times lower after boosting. However, serum anti-HBs antibodies reached the level above the cut-off value of $10 \mathrm{mIU} / \mathrm{ml}$, accepted as the minimal protective titer.

Preparation of a plant-derived prototype for orally administered vaccine

Lettuce leaves, harvested from T1 plants of S-HBsAg content $\geq 10 \mu \mathrm{g} / \mathrm{g} \mathrm{FW}$, were freeze-dried and ground into powder and stored at room temperature with a desiccating silica gel. This semi-product was mixed with different fillers and binding agents, e.g., mono- and oligosaccharides, starch, cellulose derivatives, gelatine, Arabic gum, inorganic compounds, etc. Finally, the $2: 1: 1 \mathrm{w} / \mathrm{w} / \mathrm{w}$ mixture of the powdered plant tissue with lactose as the filler and a $10 \% \mathrm{w} / \mathrm{v}$ polyvinylpyrrolidone/methylene chloride as the binding agent met the required powder density and consistency suitable for the preparation of standard tablets, i.e., $10 \times 3-\mathrm{mm}$ in size and $500 \mathrm{mg}$ in weight, with appropriate durability, friability, dissolution time, and possibility of room temperature storage (Fig. 7a). The level of total S-HBsAg in the lyophilized material reached $5 \mathrm{mg} / \mathrm{g} \mathrm{FW}$. However, the mean content of VLPstructuralized antigen was $11 \mu \mathrm{g} / \mathrm{g}$ of lyophilized tissue and $5 \mu \mathrm{g} / \mathrm{g}$ or $2.3 \mu \mathrm{g} / \mathrm{unit}$ of tablets, i.e., approximately half that of the original lyophilized material due to the added ingredients. The antigen level remained stable, i.e., without significant fluctuations, after one year of storage in dry air at room temperature, both in lyophilized tissue and in tablets (Fig. 7b). 


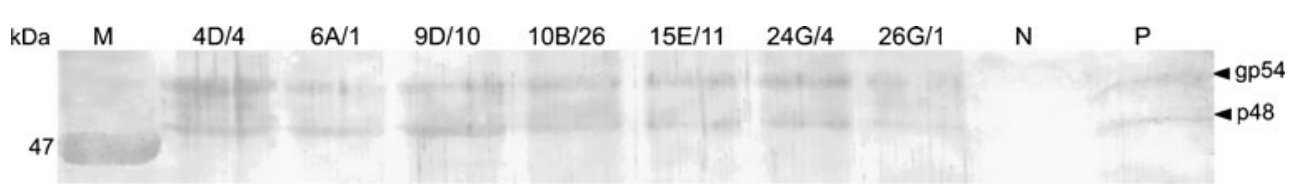

Fig. 4 Western blot analysis of S-HBsAg in lettuce. Lanes: $M$ protein molecular weight marker (MBI Fermentas); 4D/4-26G/1 analyzed plants; $N$ non-transgenic plant (negative control); $P$ S-HBsAg

\section{Discussion}

Glufosinate-resistant lettuce expressing S-HBsAg as an initial material for plant-derived prototype oral vaccine against $\mathrm{HBV}$

The presented transformation and regeneration procedure made it possible to obtain independent glufosinate-resistant lettuce line plants with a $13 \%$ efficiency. The value is lower than $70 \%$ or $31 \%$ (Enomoto et al. 1990; Curtis et al. 1994) (positive control, University of Ulm, Germany). The arrows indicate non-glycosylated (p48) and putative glycosylated (gp54) dimers (48 and $54 \mathrm{kDa}$ ) of covalently linked S-HBsAg units
Fig. 5 a-d Transmission microscope analysis (JEM1200EXII, Jeol) of virus-like particles (VLPs) assembled by plant-expressed S-HBsAg. a VLPs in the endoplasmic reticulum (ER) and the nuclear envelope $(\mathrm{Ne})$ of transgenic lettuce cell, magnification $3.6 \times 10^{4}$, bar $=100 \mathrm{~nm}$. b Nuclear envelope $(\mathrm{Ne})$ of non-transgenic cell, magnification $3.6 \times 10^{4}$, bar $=100 \mathrm{~nm}$. c VLPs inside ER vesicles, enlarged section of panel a), magnification $7.2 \times 10^{4}$, bar $=50 \mathrm{~nm} . \mathbf{d}$ Yeast-derived purified VLPs in Engerix $B^{\circledR}$, magnification $7.2 \times 10^{4}$, bar $=50 \mathrm{~nm}$
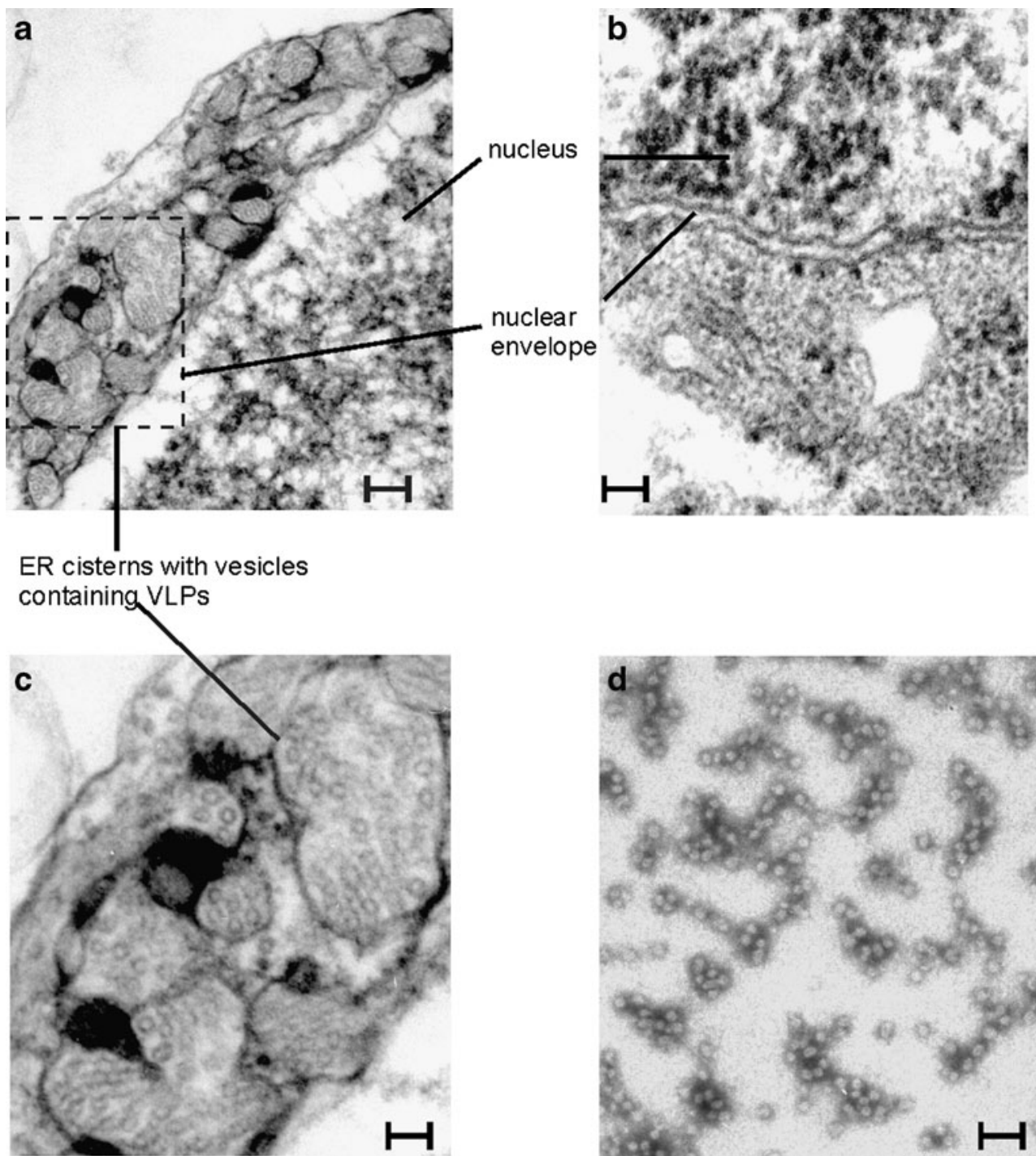

but comparable to $6 \%$ or $10 \%$ reported previously (Michelmore et al. 1987; Torres et al. 1993). The selection system based on the marker gene bar (Fig. 1), conferring resistance to strongly acting glufosinate, probably reduced the transformation rate, but, on the other hand, it guarantees high probability (90\%, see Results section) of regeneration of authentic transformants in comparison to kanamycin (Mohapatra et al. 1999). The obtained 25 plant lines were analyzed to select 12 lines characterized by a normal phenotype, stable inheritance of the S-HBs transgene 
Fig. 6 Anti-HBs secretory IgAs (S-IgAs) in feces extract (a) and total serum antibody response (b) to oral immunization with $100 \mathrm{ng} /$ dose of VLP-assembled S-HBsAg. Mice were immunized with lyophilized plant tissue (ca. $9 \mathrm{mg}$ dry weight/dose) or purified antigen, and delivered at 30- or 60-day timings. Non-transgenic lyophilized tissue or PBS were delivered to control mice at a 60-day timing. Anti-HBs antibody level (mIU/ml) responses are expressed as arithmetic means with standard deviations (SD) from results for $10 \mathrm{BALB} / \mathrm{c}$ mice at pre-immune (5 days before prime) and 10 days after each immunization, determined twice by a Hepanostika ${ }^{\circledR}$ kit (Organon Teknika, Boxtel). Statistically homogenous or significantly distinct responses for S-IgAs or total serum antibodies are marked by identical or different letter indexes, respectively (Tukey and Duncan tests, $p<0.05$, Statistica $\left.6^{(}\right)$
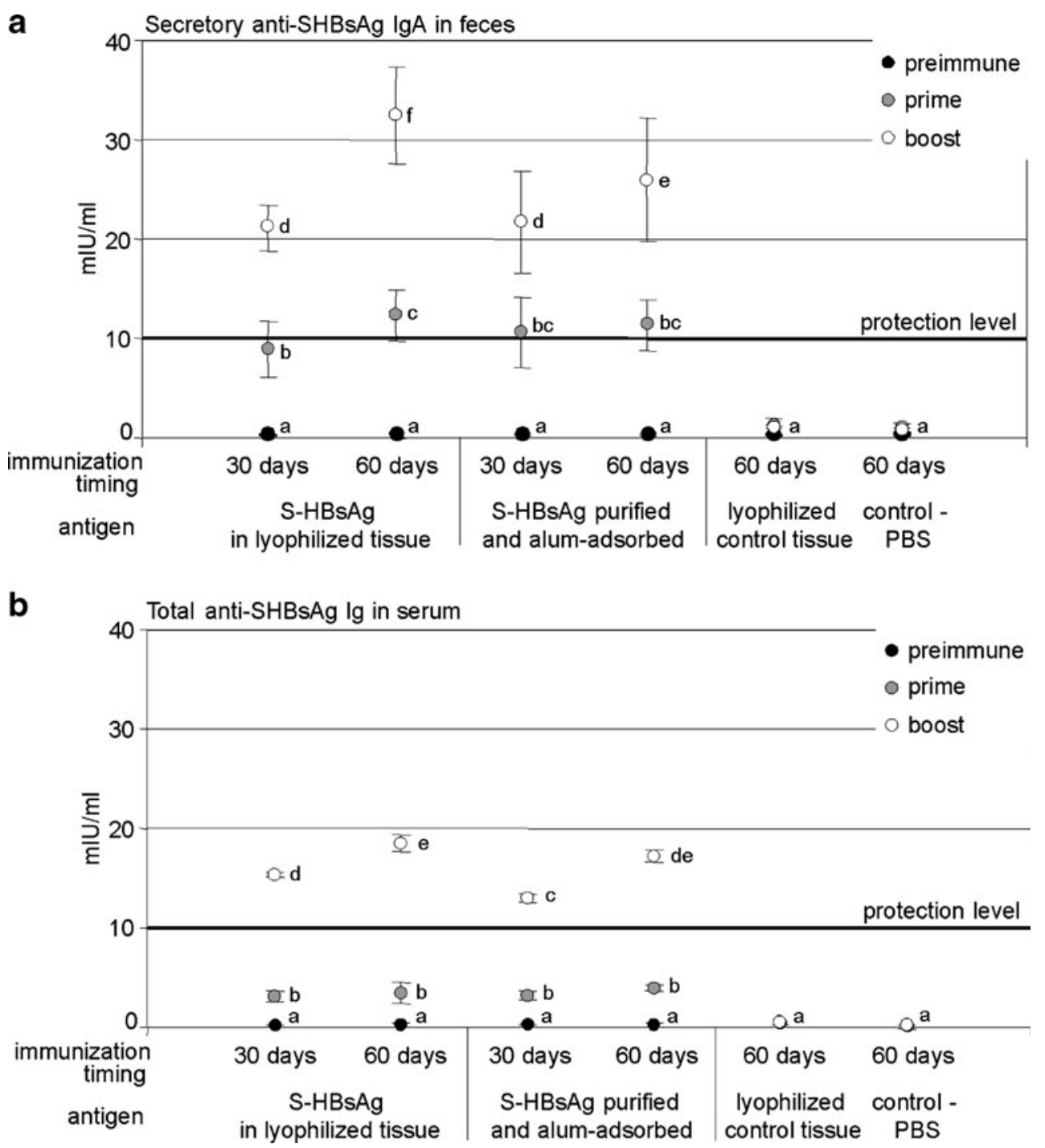

(Fig. 2), and expression of the antigen at a maintained and satisfactory level of 5-20 (and more) $\mu \mathrm{g}$ of S-HBsAg/g FW, both in T0 and T1 generations (Fig. 3). The observed average S-HBsAg expression level was similar or higher in comparison to the $0.05-16 \mu \mathrm{g} / \mathrm{g} \mathrm{FW}$ reported in previous papers (e.g., Kapusta et al. 1999; Richter et al. 2000; Kong et al. 2001; Gao et al. 2003; Sojikul et al. 2003; Joung et al. 2004; Shulga et al. 2004; Huang et al. 2005), reaching $60 \mu \mathrm{g} / \mathrm{g} \mathrm{FW}$ in some plants. The expression of native antigen forming tertiary structures was confirmed, since the Auszyme $^{\circledR}$ or other diagnostic kit assays require specific binding of a monoclonal antibody to a displayed immunodominant epitope 'a' of S-HBsAg assembled into VLPs (Jolivet-Reynaud et al. 2001; Sojikul et al. 2003). Protein bands of 48 and $54 \mathrm{kDa}$, revealed by Western blot analysis, correspond to unmodified and glycosylated S-HBsAg dimers (Fig. 4). Presumably, the dimers are extremely durable and could be observed under standard denaturing conditions, since highly hydrophobic S-HBsAg is known to dimerize immediately post-translation, and units are additionally cross-linked by multiple disulfide bridges (Bruss 2007). The dimers indicate the first step of VLP selfassembly (Bruss 2007; Patient et al. 2007), observed also in plant cells (Joung et al. 2004; Shulga et al. 2004; Huang et al. 2005). Consequently, VLPs in lettuce were structurally identical to the yeast-derived particles utilized for vaccination (Fig. 5), similarly to previous observations in plant (Kong et al. 2001) and mammalian cells (Patient et al. 2007).

In addition to the relatively high $\mathrm{S}-\mathrm{HBsAg}$ expression level, the presented transgenic lettuce represents some benefits as an oral vaccine producer. The glufosinateresistant lettuce conforms to GMO safety regulations and health requirements, since it is free of an antibioticsresistance marker gene. The cultivation of lettuce does not require special conditions and can be adapted to various local needs. Disadvantageously, the amount of harvested material is substantially lower than from typically exploited 
Fig. 7 a, b Plant-based prototype of anti-HBV vaccine specimens. a Preparation of plant-derived materials. Panels: left lettuce plants expressing $\geq 10 \mu \mathrm{g} \mathrm{S}-\mathrm{HBsAg} / \mathrm{g} \mathrm{FW}$; middle powdered lyophilized plant tissue as a semi-finished product for the preparation of various formulas of an oral vaccine; right tablets of $10 \times 3 \mathrm{~mm}$ in size and $500 \mathrm{mg}$ in weight, containing a specific dose of $\mathrm{S}-\mathrm{HBsAg}$. b The level of total and VLP-assembled S-HBsAg in powdered lyophilized tissue and $1 \mathrm{~g}$ and 1 unit of tablets, freshly prepared and stored for one year. S-HBsAg content was calculated in $\mu \mathrm{g} / \mathrm{g}$ of dry weight (DW) as an arithmetic mean and standard deviation (SD) from ten polyclonal ELISA or monoclonal Auszyme ${ }^{\circledR}$ assays a

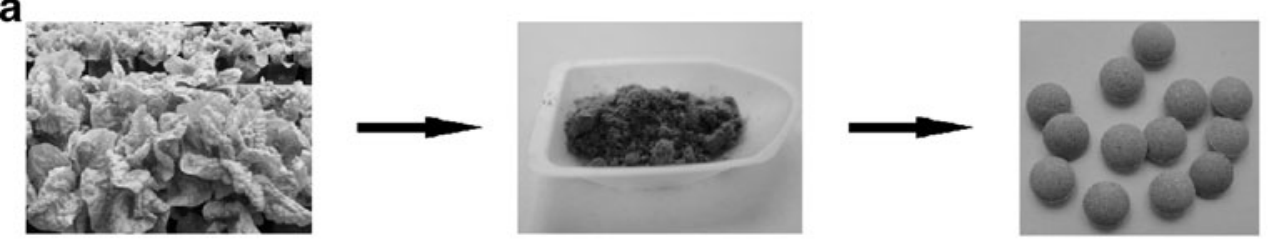

b

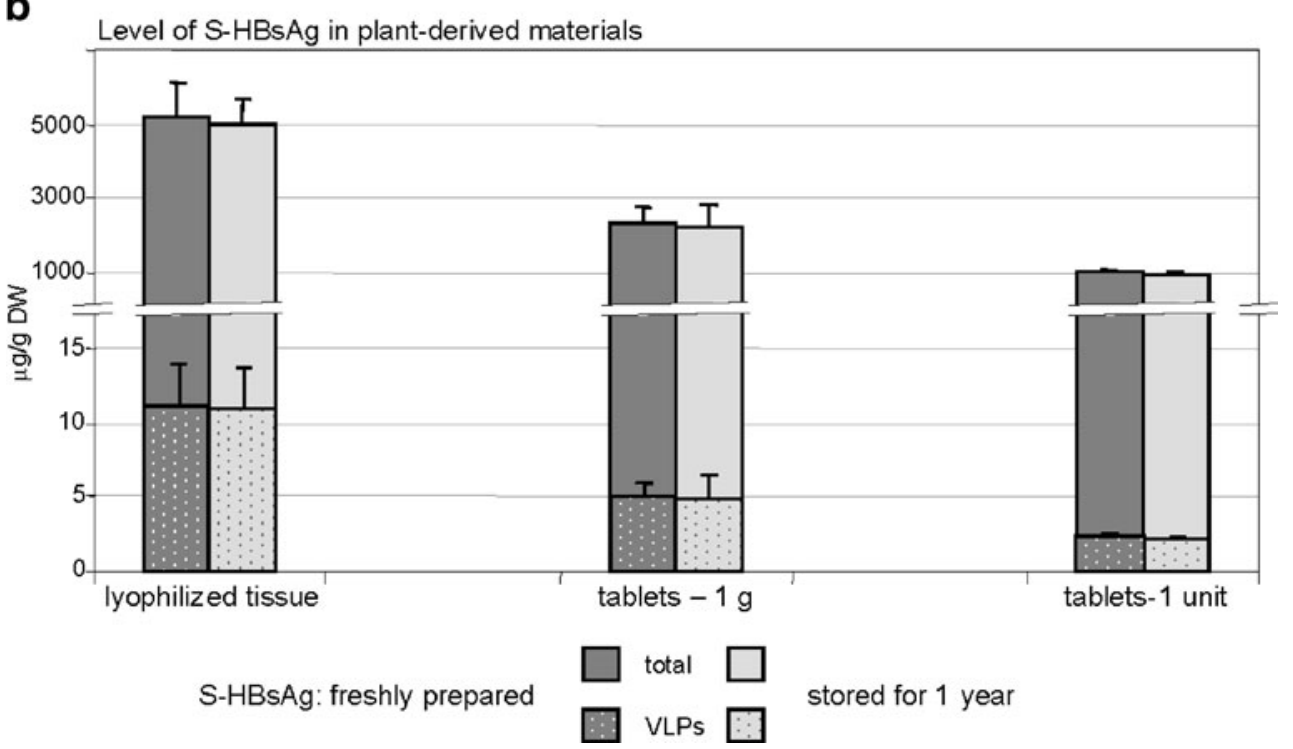

tobacco or potato. However, lettuce is naturally free of harmful alkaloids, etc., and the antigen concentration can be increased by lyophilization. Lettuce leaves are easy to be freeze-dried in comparison to tomatoes, bananas, tubers, or carrot. Moreover, though lyophilization is necessary, SHBsAg expression level in leaves is many times higher than in naturally dry seeds (Sunil Kumar et al. 2006).

Oral immunization with lyophilized plant tissue containing S-HBsAg

Potential plant-based oral vaccines require suitable antigen formulations and immunization protocols to ensure antigen stability through the alimentary tract and a balance between immune response and oral tolerance (Holmgren and Czerkinsky 2005; Mestecky et al. 2007).

The presented results show that a relatively low dosage, i.e., $100 \mathrm{ng}$ of S-HBsAg VLPs, and an extended interval, up to 60 days between oral prime and boost, induced mucosal and systemic efficient immunization with a small amount of lyophilized tissue, ca. $9 \mathrm{mg}$ (Fig. 6). The level of S-IgAs was somewhat higher than serum antibodies, similarly to some previous observations (Shchelkunov et al. 2006; Jiang et al. 2007). Response of the gut-associated lymphoid tissue (GALT) to the antigen administered solely orally could surpass periphery response, since GALT interacts with such antigens as the first line of the whole immune system and also mucosal membranes limit deeper antigen penetration (Czerkinsky et al. 1993), but on the other hand, mucosal immunity can broaden the protection range against penetrating pathogens (Isaka et al. 2001; Brandtzaeg 2003). Nevertheless, the antigen delivered on the described schedule elicited a statistically significant mucosal and systemic response in comparison to the preimmune and the control, finally reaching a titer $\geq 10$ $\mathrm{mIU} / \mathrm{ml}$ of anti-HBs total serum antibodies (Fig. 6b), which is considered as the minimal protective response (International Group 1988; Brocke et al. 2005). A low S$\mathrm{HBsAg}$ dosage induced significant and similar immune responses in individual mice, as demonstrated by low SDs (Fig. 6), probably due to the fact that the GALT is a tuned immune milieu, where even small amounts of antigens organized into VLPs or other tertiary structures are recognized and processed (Mestecky et al. 2007). Consequently, the local immune response develops and immunity can be transmitted from the mucosa to the periphery. The GALT determines adaptive immunity versus unresponsiveness depending on antigen structure dosage and duration of its exposure (Mowat 2003; Pamer 2007). Accordingly, low antigen dosage applied in the study was probably conducive to local and systemic immune response, while oral tolerance can be induced by high dosage and/or repeated frequent antigen delivery (Peng et al. 1989; Friedman and Weiner 1994).

Other reports on oral immunization with S-HBsAg or other antigens corroborate the positive effect of a low 
antigen dosage and extended administration on immune response. A 5-ng dose of alum-adsorbed S-HBsAg administered orally to mice over 8 weeks induced a significantly higher response than a 500-ng dose delivered over 2 weeks (Kapusta et al. 2010), or the response was higher and reached the $\geq 10 \mathrm{mIU} / \mathrm{ml}$ protective level in human volunteers fed with lettuce on days 1 and 60 (Kapusta et al. 1999) than in those fed on days 1, 7, and 30 (Kapusta et al. 2001) with 1-2 $\mu$ g of S-HBsAg per person. Accordingly, low nanogram doses of S-HBsAg elicited immune response both in the mucosa and the periphery, while higher doses stimulated tolerance (Kostrzak et al. 2009); primary humoral response was triggered at an oral delivery of $30 \mathrm{ng}$ of fusion antigen TBI-HBsAg to mice and the successive boost by DNA immunization only slightly increased the level of anti-HBs antibodies (Shchelkunov et al. 2006). The efficacy of oral immunization conducted at a low, even nanogram, dosage and at extended timing was also confirmed for plant-expressed CT-B (Arakawa et al. 1998) or LT-B (Lamphear et al. 2002; Beyer et al. 2007). Also for dietary allergen ovalbumin, low dosage elicited immune response, while suppression was induced by high-dose early boosting (Franco et al. 1998).

Plant-associated S-HBsAg, delivered on the reported schedule and without exogenous adjuvants, elicited an immune response at the nominally protective level, although the antibody titer was several times lower than that usually triggered in cases of S-HBsAg parenteral administration (Brocke et al. 2005) or previous oral immunization trials using microgram doses of the antigen. However, in those experiments, it was necessary to combine the oral delivery of (in most cases) CT-Badjuvanted S-HBsAg with parenteral (prime or boost) vaccination (Richter et al. 2000; Kong et al. 2001; Gao et al. 2003; Mason et al. 2003; Joung et al. 2004; Huang et al. 2005; Thanavala et al. 2005). A similar trend of high immune responses following parenteral-oral abundant antigen delivery was also observed for other antigens, e.g., Norwalk virus, rabies glycoprotein, or plague. On the other hand, parenterally-orally administered micrograms of the alum-adsorbed antigen, but unadjuvanted with CT-B (Kong et al. 2001), or the purified and encapsulated antigen adjuvanted with bile salt or CpG oligos (Borges et al. 2007; Shukla et al. 2008), induced immune response comparable to the present results. Immune reaction at the level 10-30 $\mathrm{mIU} / \mathrm{ml}$ requires to be enhanced though. However, toxinderived adjuvants are not approved for use in humans, hence, any GALT immunostimulator must be meticulously explored to eliminate possible hazardous side-effects (Brandtzaeg 2003).

On the other hand, it might be supposed that some phytochemicals could synergistically affect the immunogenicity of plant-expressed antigens as in the case of presented results or plant-expressed CT-B (Jiang et al. 2007). Medicinal plants are known for their natural immunostimulating or anti-microbial activity due to such secondary metabolites as lectins, saponins, and others. Lettuce does not contain significant amounts of these substances though, except terpenoids in latex sap, characteristic for the Asteraceae family. Moreover, some commonly occurring plant components have adjuvant properties, e.g., unmethylated CpGs motifs of DNA (Wang et al. 2002) or carotenoids, etc. Presumably, plant tissue together with the above-mentioned compounds protected and increased the immunogenicity of S-HBsAg in lettuce, since the reaction elicited by plant-associated antigen was somewhat higher than that induced by the purified and alum-adsorbed antigen (Fig. 6). Hence, it might be carefully assumed that raw edible plants can be used at the same time as an oral vaccine producer and, at least partially, as a source of endogenous adjuvants too.

A plant-derived durable prototype for an orally administered vaccine against hepatitis B

Although oral immunization based on the consumption of raw transgenic plants containing S-HBsAg was demonstrated to induce an immune response in mice (Kapusta et al. 1999; Richter et al. 2000; Kong et al. 2001; Gao et al. 2003; Joung et al. 2004) and humans (Kapusta et al. 1999, 2001; Mason et al. 2003; Thanavala et al. 2005), immunization by feeding encounters logistical and medical contraindications (Kirk et al. 2005). Antigen instability in stored plant tissue and splitting of an initial dose of 'edible vaccine', both fresh and dry, into lower undefined subdoses, repeatedly exposed to GALT, and adsorbed as a dietary component (Swarbrick et al. 1979), subsequently is conducive to tolerance induction. Moreover, potential plantbased oral vaccines considered for mass immunization against HB and other diseases (Aziz et al. 2007; Mestecky et al. 2008) should be simple to administer. Expectations for plant-derived oral vaccines can be met by the application of freeze-dried plant materials, which was initiated in recent years in immunization experiments with monomeric and oligomeric antigens, such as CT-B (Huang et al. 2005), LT-B (Rosales-Mendoza et al. 2009), measles hemagglutinin (Webster et al. 2006), and others.

Here, a novel prototype plant-based anti-HBV vaccine in tablet form prepared from freeze-dried lettuce highly $(\geq 10 \mu \mathrm{g} / \mathrm{g} \mathrm{FW}$ ) expressing VLP-assembled S-HBsAg is proposed (Fig. 7a). The administration of durable powdered freeze-dried plant tissue made it possible to concentrate and standardize antigen content throughout vaccine doses and would facilitate delivery of the antigen in a size-reduced specimen under a controlled regime (Figs. 6 and 7). However, during lyophilization, an at least $90 \%$ decrease 
of S-HBsAg VLPs content was recorded when compared to fresh tissue (Fig. 3) and that observed in freeze-dried tissue (Fig. 7b), considering that the dry weight is $5-10 \% \mathrm{FW}$. Advantageously, the low dose of VLPs applied in a 'single shot', avoiding extended exposure in sub-portions, appeared to be sufficient to induce local and systemic humoral response at an adequate protection level (Fig. 6). However, potential industrial production of the oral vaccine would require the optimization of freeze-drying parameters to effectively retain the VLPs.

The tablet form of a potential vaccine specimen seems to be feasible to produce, durable in storage even at room temperature, and easy to use, which is especially important in regions with an underdeveloped medical infrastructure. A compact tablet form made it possible to concentrate the dose of antigen assembled into immunogenic VLPs $(2.3 \mu \mathrm{g} / \mathrm{unit})$ in a relatively small weight and volume (see Results section), while the same antigen dose would have to be contained in a 4-5 times bigger capsule or other formula containing loose powder. Due to the powdery structure, high hygroscopicity, and low density of milled lyophilized tissue, the tablet filler, i.e., lactose, and the binding agent, i.e., polyvinylpyrrolidone, had to be established experimentally from among standard components to facilitate the compression of tablets of proper parameters (see Results section). Moreover, tablets, as well as lyophilized tissue, are characterized by the stability (95-98\%) of S-HBsAg content for at least one year of room temperature storage (Fig. 7b). Tablets indicate a direction for the development of a compacted prototype oral vaccine, convenient for use and distribution, and may facilitate human immunization trials. It could be assumed that data acquired on immunization efficacy will contribute to further tablet optimization to enhance immune response, e.g., with the addition of adjuvants, immunomodulators, etc.

\section{Conclusions}

Research on a plant-derived vaccine against hepatitis $\mathrm{B}$ virus (HBV) requires further detailed studies on mucosal and systemic immune response and possible tolerance induction. Parameters of oral vaccination, such as dosage, timing, adjuvants, antigen formulation, immunization routes, etc., will have to be accurately adjusted. The presented results and other reports allow to carefully presume that immunity, probably balanced with tolerance, may be induced by an appropriate immunization protocol, based on a calibrated, extended delivery timing of generally low doses of lyophilized tissue containing small surface antigen of HBV (S-HBsAg). Lettuce or other plants efficiently expressing native S-HBsAg, resistant to herbicides and innately free of harmful substances, could be an initial material for the preparation of durable and reliable oral vaccine as tablets or other formulas. The reported results constitute a basis for the elaboration of an alternative or supplementary oral vaccine, easily implementable for HB immunization programs.

Acknowledgments This work was supported by grant nos. 2 P04B 00127 and N401-O/0026/32 from the Polish State Committee for Scientific Research and under the auspices of Medana Pharma Ltd., Sieradz, Poland. We are grateful to Kacper Jankowski for his help in the lettuce transformation, Prof. Adam Woźny (Adam Mickiewicz University of Poznań, Poland) for his support in the microscopic analysis, Prof. Bogusław Szewczyk (University of Gdańsk, Poland) for providing the anti-SHBsAg rabbit serum, Prof. Reinhold Schirmbeck (University of Ulm, Germany) for his kind gift of the unadjuvanted S-HBsAg, and Dr. David Tepfer (INRA Versailles, France) for his critical reading of the manuscript.

Open Access This article is distributed under the terms of the Creative Commons Attribution Noncommercial License which permits any noncommercial use, distribution, and reproduction in any medium, provided the original author(s) and source are credited.

\section{References}

Arakawa T, Chong DKX, Langridge WHR (1998) Efficacy of a food plant-based oral cholera toxin B subunit vaccine. Nat Biotechnol 16:292-297

Aziz MA, Midha S, Waheed SM, Bhatnagar R (2007) Oral vaccines: new needs, new possibilities. Bioessays 29:591-604

Becker D, Kemper E, Schell J, Masterson R (1992) New plant binary vectors with selectable markers located proximal to the left TDNA border. Plant Mol Biol 20:1195-1197

Beyer AJ, Wang K, Umble AN, Wolt JD, Cunnick JE (2007) Lowdose exposure and immunogenicity of transgenic maize expressing the Escherichia coli heat-labile toxin B subunit. Environ Health Perspect 115:354-360

Borges O, Tavares J, de Sousa A, Borchard G, Junginger HE, Cordeiro-da-Silva A (2007) Evaluation of the immune response following a short oral vaccination schedule with hepatitis B antigen encapsulated into alginate-coated chitosan nanoparticles. Eur J Pharm Sci 32:278-290

Brandtzaeg P (2003) Role of secretory antibodies in the defence against infections. Int J Med Microbiol 293:3-15

Brocke P, Schaefer S, Melber K, Jenzelewski V, Müller F, Dahlems U, Bartelsen O, Park K-N, Janowicz ZA, Gellissen G (2005) Recombinant hepatitis $\mathrm{B}$ vaccines: disease characterization and vaccine production. In: Gellissen G (ed) Production of recombinant proteins: novel microbial and eukaryotic expression systems. Wiley-VCH Verlag $\mathrm{GmbH} \&$ Co. KGaA, Weinheim, pp 319-359

Bruss V (2007) Hepatitis B virus morphogenesis. World J Gastroenterol 13:65-73

Curtis IS, Power JB, Blackhall NW, de Laat AMM, Davey MR (1994) Genotype-independent transformation of lettuce using Agrobacterium tumefaciens. J Exp Bot 45:1441-1449

Czerkinsky C, Svennerholm A-M, Holmgren J (1993) Induction and assessment of immunity at enteromucosal surfaces in humans: implications for vaccine development. Clin Infect Dis 16(Suppl 2):S106-S116

Doyle JJ, Doyle JL (1990) Isolation of plant DNA from fresh tissue. Focus 12:13-15 
Enomoto S, Itoh H, Ohshima M, Ohashi Y (1990) Induced expression of a chimeric gene construct in transgenic lettuce plants using tobacco pathogenesis-related protein gene promoter region. Plant Cell Rep 2:6-9

Franco L, Benedetti R, Ferek GA, Massouh E, Fló J (1998) Priming or tolerization of the B- and Th2-dependent immune response by the oral administration of OVA-DNP is determined by the antigen dosage. Cell Immunol 190:1-11

Friedman A, Weiner HL (1994) Induction of anergy or active suppression following oral tolerance is determined by antigen dosage. Proc Natl Acad Sci USA 91:6688-6692

Gao Y, Ma Y, Li M, Cheng T, Li S-W, Zhang J, Xia N-S (2003) Oral immunization of animals with transgenic cherry tomatillo expressing HBsAg. World J Gastroenterol 9:996-1002

Goldstein ST, Fiore AE (2001) Toward the global elimination of hepatitis B virus transmission. J Pediatr 139:343-345

Holmgren J, Czerkinsky C (2005) Mucosal immunity and vaccines. Nat Med 11(Suppl 4):S45-S53

Huang Z, Elkin G, Maloney BJ, Beuhner N, Arntzen CJ, Thanavala Y, Mason HS (2005) Virus-like particle expression and assembly in plants: hepatitis B and Norwalk viruses. Vaccine 23:1851-1858

International Group (1988) Immunisation against hepatitis B. Lancet 1:875-876

Isaka M, Yasuda Y, Mizokami M, Kozuka S, Taniguchi T, Matano K, Maeyama J, Mizuno K, Morokuma K, Ohkuma K, Goto N, Tochikubo K (2001) Mucosal immunization against hepatitis B virus by intranasal co-administration of recombinant hepatitis $B$ surface antigen and recombinant cholera toxin B subunit as an adjuvant. Vaccine 19:1460-1466

Jiang XL, He ZM, Peng ZQ, Qi Y, Chen Q, Yu SY (2007) Cholera toxin $\mathrm{B}$ protein in transgenic tomato fruit induces systemic immune response in mice. Transgenic Res 16:169-175

Jolivet-Reynaud C, Lésenéchal M, O'Donnell B, Becquart L, Foussadier A, Forge F, Battail-Poirot N, Lacoux X, Carman W, Jolivet M (2001) Localization of hepatitis B surface antigen epitopes present on variants and specifically recognised by antihepatitis B surface antigen monoclonal antibodies. J Med Virol 65:241-249

Joung YH, Youm JW, Jeon JH, Lee BC, Ryu CJ, Hong HJ, Kim HC, Joung H, Kim HS (2004) Expression of the hepatitis B surface S and preS2 antigens in tubers of Solanum tuberosum. Plant Cell Rep 22:925-930

Kao JH, Chen DS (2002) Global control of hepatitis B virus infection. Lancet Infect Dis 2:395-403

Kapusta J, Modelska A, Figlerowicz M, Pniewski T, Letellier M, Lisowa O, Yusibov V, Koprowski H, Plucienniczak A, Legocki AB (1999) A plant-derived edible vaccine against hepatitis B virus. FASEB J 13:1796-1799

Kapusta J, Modelska A, Pniewski T, Figlerowicz M, Jankowski K, Lisowa O, Plucienniczak A, Koprowski H, Legocki AB (2001) Oral immunization of human with transgenic lettuce expressing hepatitis B surface antigen. Adv Exp Med Biol 495:299-303

Kapusta J, Pniewski T, Wojciechowicz J, Bociag P, Płucienniczak A (2010) Nanogram doses of alum-adjuvanted HBs antigen induce humoral immune response in mice when orally administered. Arch Immunol Ther Exp (Warsz) 58:143-151

Kirk DD, McIntosh K, Walmsley AM, Peterson RKD (2005) Risk analysis for plant-made vaccines. Transgenic Res 14:449-462

Kocjan G, Samardakiewicz S, Woźny A (1996) Regions of lead uptake in Lemna minor plants and localization of this metal within selected parts of the root. Biol Plant 38:107-117

Kong Q, Richter L, Yang YF, Arntzen CJ, Mason HS, Thanavala Y (2001) Oral immunization with hepatitis B surface antigen expressed in transgenic plants. Proc Natl Acad Sci USA 98:11539-11544
Kostrzak A, Cervantes Gonzalez M, Guetard D, Nagaraju DB, WainHobson S, Tepfer D, Pniewski T, Sala M (2009) Oral administration of low doses of plant-based HBsAg induced antigen-specific IgAs and IgGs in mice, without increasing levels of regulatory T cells. Vaccine 27:4798-4807

Lamphear BJ, Streatfield SJ, Jilka JM, Brooks CA, Barker DK, Turner DD, Delaney DE, Garcia M, Wiggins B, Woodard SL, Hood EE, Tizard IR, Lawhorn B, Howard JA (2002) Delivery of subunit vaccines in maize seed. J Control Release 85:169-180

Mason HS, Thanavala Y, Arntzen CJ, Richter E (2003) Expression of immunogenic hepatitis B surface antigens in transgenic plants. US patent $6551820 \mathrm{~B} 1$

McGarvey P, Kaper JM (1991) A simple and rapid method for screening transgenic plants using the PCR. Biotechniques $11: 428-432$

Mestecky J, Russell MW, Elson CO (2007) Perspectives on mucosal vaccines: is mucosal tolerance a barrier? J Immunol 179:56335638

Mestecky J, Nguyen H, Czerkinsky C, Kiyono H (2008) Oral immunization: an update. Curr Opin Gastroenterol 24:713-719

Michelmore R, Marsh E, Seely S, Landry B (1987) Transformation of lettuce (Lactuca sativa) mediated by Agrobacterium tumefaciens. Plant Cell Rep 6:439-442

Mohapatra U, McCabe MS, Power JB, Schepers F, van der Arend A, Davey MR (1999) Expression of the bar gene confers herbicide resistance in transgenic lettuce. Transgenic Res 8:33-44

Mowat AM (2003) Anatomical basis of tolerance and immunity to intestinal antigens. Nat Rev Immunol 3:331-341

Pamer EG (2007) Immune responses to commensal and environmental microbes. Nat Immunol 8:1173-1178

Patient R, Hourioux C, Sizaret P-Y, Trassard S, Sureau C, Roingeard P (2007) Hepatitis B virus subviral envelope particle morphogenesis and intracellular trafficking. J Virol 81:3842-3851

Peng HJ, Turner MW, Strobel S (1989) The kinetics of oral hyposensitization to a protein antigen are determined by immune status and the timing, dose and frequency of antigen administration. Immunology 67:425-430

Pniewski T, Kapusta J (2005) Efficiency of transformation of Polish cultivars of pea (Pisum sativum L.) with various regeneration capacity by using hypervirulent Agrobacterium tumefaciens strains. J Appl Genet 46:139-147

Richter LJ, Thanavala Y, Arntzen CJ, Mason HS (2000) Production of hepatitis B surface antigen in transgenic plants for oral immunization. Nat Biotechnol 18:1167-1171

Rosales-Mendoza S, Alpuche-Solís AG, Soria-Guerra RE, MorenoFierros L, Martínez-González L, Herrera-Díaz A, Korban SS (2009) Expression of an Escherichia coli antigenic fusion protein comprising the heat labile toxin B subunit and the heat stable toxin, and its assembly as a functional oligomer in transplastomic tobacco plants. Plant J 57:45-54

Shchelkunov SN, Salyaev RK, Pozdnyakov SG, Rekoslavskaya NI, Nesterov AE, Ryzhova TS, Sumtsova VM, Pakova NV, Mishutina UO, Kopytina TV, Hammond RW (2006) Immunogenicity of a novel, bivalent, plant-based oral vaccine against hepatitis B and human immunodeficiency viruses. Biotechnol Lett 28:959-967

Shukla A, Khatri K, Gupta PN, Goyal AK, Mehta A, Vyas SP (2008) Oral immunization against hepatitis B using bile salt stabilized vesicles (bilosomes). J Pharm Pharm Sci 11:59-66

Shulga NYA, Rukavtsova EB, Krymsky MA, Borisova VN, Melnikov VA, Bykov VA, Buryanov YI (2004) Expression and characterization of hepatitis B surface antigen in transgenic potato plants. Biochemistry (Mosc) 69:1158-1164

Sojikul P, Buehner N, Mason HS (2003) A plant signal peptidehepatitis B surface antigen fusion protein with enhanced stability and immunogenicity expressed in plant cells. Proc Natl Acad Sci USA 100:2209-2214 
Sunil Kumar GB, Srinivas L, Ganapathi TR, Bapat VA (2006) Hepatitis B surface antigen expression in transgenic tobacco (Nicotiana tabacum) plants using four different expression cassettes. Plant Cell Tissue Organ Cult 84:315-323

Swarbrick ET, Stokes CR, Soothill JF (1979) Absorption of antigens after oral immunisation and the simultaneous induction of specific systemic tolerance. Gut 20:121-125

Thanavala Y, Mahoney M, Pal S, Scott A, Richter L, Natarajan N, Goodwin P, Arntzen CJ, Mason HS (2005) Immunogenicity in humans of an edible vaccine for hepatitis B. Proc Natl Acad Sci USA 102:3378-3382
Torres AC, Cantliffe DJ, Laughner B, Bieniek M, Nagata R, Ashraf M, Ferl RJ (1993) Stable transformation of lettuce cultivar South Bay from cotyledon explants. Plant Cell Tissue Organ Cult 34:279-285

Wang Y, Wang W, Li N, Yu Y, Cao X (2002) Activation of antigenpresenting cells by immunostimulatory plant DNA: a natural resource for potential adjuvant. Vaccine 20:2764-2771

Webster DE, Smith SD, Pickering RJ, Strugnell RA, Dry IB, Wesselingh SL (2006) Measles virus hemagglutinin protein expressed in transgenic lettuce induces neutralising antibodies in mice following mucosal vaccination. Vaccine 24:3538-3544 